\title{
Stochastic Model and Method of Optimization of Operation Modes of a Group of Artesian Wells in Water Supply Systems
}

\author{
Andrei Tevyashev'1, Olga Matviyenko², Glib Nikitenko³ \\ Kharkiv National University of Radio Electronics \\ Lenina avenue 16, Kharkov, Ukraine, 61166 \\ 1tad45ua@gmail.com, orcid.org/0000-0002-2846-7089 \\ 2olga_mat@ukr.net, orcid.org/ 0000-0001-7492-7616 \\ 3gvnikitenko@gmail.com, orcid.org/ 0000-0001-5954-0712
}

Received 05.07.2021, accepted after revision 10.09.2021

https://doi.org/10.32347/uwt2021.11.1501

\begin{abstract}
Groups of spatially distributed wells interconnected by sections of pipelines (a common collector) supplying water to a clean water reservoir are used in water supply systems in order to provide drinking water to settlements. A group of wells together with a clean water reservoir is called a water intake facility of the water supply system. Further, water is supplied from the clean water reservoir to consumers in settlements by means of second stage pumping stations. In terms of each well the operating mode of the submersible pumping unit, i.e. the position of its operating point at a fixed moment in time, depends on the actual values of many internal and external factors: dynamic water level in the well; the actual characteristics of the pumping unit; the position of the final control elements (drive speed, opening degree of the regulating valve); hydraulic resistances of pipeline sections of the water intake facility; the water level in the clean water reservoir; the number and operating modes of pumping units in other wells of the water intake facility.

The paper describes a deterministic model of a water intake well. At the same time, the processes of water consumption are random processes, since they depend on many uncontrolled and unmanageable factors. The parameters of the technological equipment of the water intake facility are also random values, since they are estimated from experimental data of finite length.

Therefore, a stochastic model of a water intake well is also proposed. A model of a quasistationary operation mode of a water intake facili-
\end{abstract}

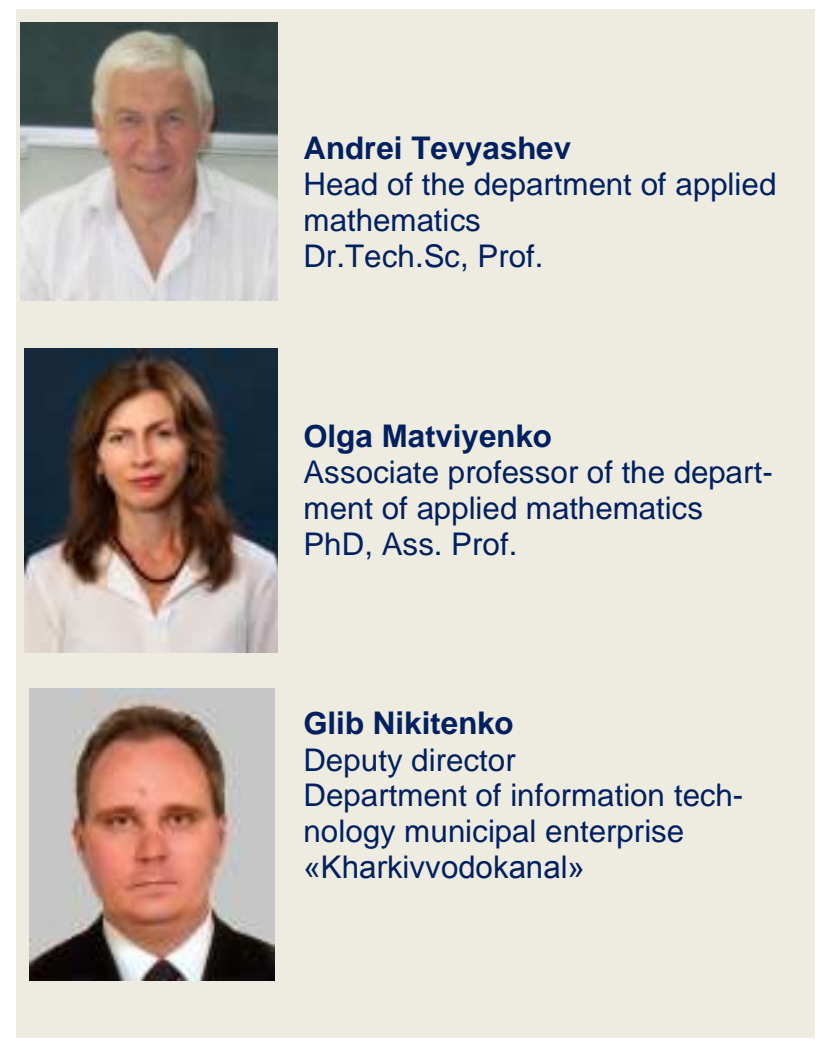

ty, which is used to optimize the operation of a group of artesian wells operating on a common collector, is considered.

Keywords: artesian well; water supply system; optimization; stochastic model, pumping unit, water intake facility. 


\section{INTRODUCTION}

Water supply to large cities is carried out, as a rule, from surface water bodies - lakes, storage lakes, large rivers, that is, from sources with significant water reserves. In this case, the water supply scheme includes: first stage pumping stations, which take water directly from the surface water bodies; water treatment (purification) system; second stage and third stage pumping stations, which pump clean water over long distances and deliver it to settlements.

In case the settlement is located in an area where there are no large open water sources, or the geographical position of the settlement allows the use of groundwater, in this case, artesian wells are used as a source of water supply. Usually small settlements are supplied with water from artesian wells. Artesian wells are widely used for water supply to villages, industrial water supply, for irrigation (irrigation systems), in the mining industry, for lowering the level of groundwater. The advantage of using artesian wells to supply the population with drinking water is that water is extracted from great depths and purified using natural filters. Thus, the cost of water treatment is significantly reduced. The disadvantages of using artesian wells are usually low well productivity, a strong dependence of the well water volume on climatic and weather conditions, well depletion as a result of largescale construction projects or the extraction of natural resources, such as shale gas.

\section{ANALYSIS OF RECENT RESEARCH AND PUBLICATIONS}

In the [1] scientific paper, the mutual influence of a group of interacting wells is considered to assess their productivity. The model of a group of wells is based on the analysis of the distances between them and is implemented in the SUMULINK environment. These studies are useful for well design, but they do not consider the possibility of optimizing the operation of a group of wells.

The [2] scientific paper solves the problem of determining the optimal set of operating equipment, but does not take into account twozone or three-zone tariffs for electricity.

The [3] scientific paper considers the optimization of the operation of a group of wells for a two-zone tariff for electricity by turning on/off the pumps, but does not investigate the influence of the pumps on each other during simultaneous operation.

In the [4] scientific paper, the operation of the well is optimized by changing the pump suspension height. However, such measures are suitable for one well and will be technically difficult to implement for a group of wells.

In the [5] scientific paper, methods for optimizing well performance based on monitoring well parameters and real-time control are considered. These results are important for highly sophisticated wells. In addition, the research is devoted to oil wells. For artesian water wells, such methods would be too costly.

In the [6] scientific paper, operation of a group of wells is considered, the optimization is carried out in terms of the well rate.

All of the above mentioned scientific papers are devoted to modeling and optimization of well operation, but each has its own approach to solving this problem.

In this paper, we propose the following approach to optimizing the operation of a group of artesian wells: choosing the optimal operating mode of the entire system by calibrating the pumping units on the wells to achieve their coordinated operation.

\section{THE AIM OF THE STUDY}

The purpose of the scientific paper is to build a stochastic model of quasi-stationary operation modes of the water-intake facility and use the resulting model to optimize its operation.

The following tasks were solved in the furtherance of this purpose:

- formulation of a deterministic mathematical model of an artesian well;

- formulation of a stochastic mathematical model of an artesian well;

- formulation of a stochastic model of the water-intake facility operation; 
- development of a method for optimizing the operating modes of a water-intake facility with artesian wells;

- carrying out a computational experiment in order to optimize the operating modes of the water-intake facility with artesian wells.

\section{RESULTS OF THE RESEARCH}

Individual water-intake wells are widely used in individual farms. Productive efficiency of individual wells becomes insufficient for providing water to settlements, therefore, groups (clusters) of spatially distributed wells are used in water supply systems, interconnected by sections of pipelines (a common collector), supplying water to a filtered-water reservoir (FWR). A group of wells together with an FWR is called a water-intake facility (WIF) of the water supply system (WSS). Further, water is supplied to consumers in settlements from the FWR by second stage pumping stations (PS). The operating mode of the pumping unit (PU), that is, the position of the operating point at each moment of time in each well depends on the actual values of many internal and external factors: dynamic water level in the well; actual characteristics of a PU; the position of the regulating bodies (drive speed, opening degree of the control valve); hydraulic resistances of the air intake pipelines sections; water level in the FWR; the number and modes of a PU operation in other wells of the WIF. [7 - 10].

\section{Deterministic water well model}

Electrical centrifugal water pumping (ECWP) units are widely used for water supply from wells. Without loss of generality, let us consider the main characteristics of these units. ECWP units are designed to supply water from wells: with total salinity (dry residue) of max. $1500 \mathrm{mg} / \mathrm{l}$; with a hydrogen index (pH) from 6.5 to 9.5 ; with temperatures up to $25^{\circ} \mathrm{C}$; with $0.01 \%(100 \mathrm{~g} / \mathrm{m} 3)$ mass fraction of solid mechanical impurities; max. $350 \mathrm{mg} / \mathrm{l}$ chloride content; max. $500 \mathrm{mg} / \mathrm{I}$ sulfates, 1.5 mg / 1 hydrogen sulfide. The units can be used for municipal, industrial and agricultural water supply, for irrigation, lowering the groundwater level and for daily living needs. The unit size designation includes the ECWP letters, which mean: $\mathrm{E}$ - driven by a submersible electric motor; C - centrifugal; WP - for water pumping (supply) plus numbers, for example ECWP 8-40-90, consecutively indicating: 8 allowable casing string diameter in inches (diameter in $\mathrm{mm}$, reduced 25 times and rounded, i.e. $8 * 25=200 \mathrm{~mm} ; 40-$ nominal flow rate (in $\mathrm{m} 3 / \mathrm{h}$ ); 90 - pressure (in $\mathrm{m}$ ) corresponding to the nominal flow. Pumping units are manufactured in three versions:

- ECWP unit in standard design;

- ECWP unit with the letter S (body parts made of stainless steel);

- ECWP with the letters SSI (body parts made of stainless steel, impellers made of stainless steel, graphite thrust bearing).

Specifications for ECWP 8-40-90. Minimum allowable well Casing string diameter in inches (diameter in $\mathrm{mm}$, reduced 25 times and rounded) -8 "(inches). Rated water supply is $40 \mathrm{~m} 3 / \mathrm{h}$. Nominal water pressure (clearance height) is $90 \mathrm{~m}$. Rated power is $16 \mathrm{~kW}$. Rated current is $36 \mathrm{~A}$. Unit weight is $104 \mathrm{~kg}$. Pump length is $1600 \mathrm{~mm}$. Number of pump stages is 8. Connection method is a steel pipe according to GOST 8732-78 $108 * 8$, outer diameter $108.0 \mathrm{~mm}$, pipe wall thickness $8.0 \mathrm{~mm}$. The units operate in continuous mode from a 3phase alternating current network with $380 \mathrm{~V}$ voltage and $50 \mathrm{~Hz}$ frequency.

The PU consists of a centrifugal pump and a submersible electric motor. There is a mesh, that serves to retain large particles contained in the pumped out water, on the suction part of the unit. Each stage (section) of the pump consists of a cage, an impeller and a vane outlet. The position of the impellers on the shaft is fixed with keys, spacers and protective sleeves. The pump shaft rotates in radial plain bearings, which are lubricated by the pumped water. A check valve is located in the upper part of the pump, which serves to retain the liquid column in the riser pipes when the pump stops and ensures a smooth start during repeated starts. The diagram of a pumping unit installation in the well is shown in Fig. 1 [14]. 


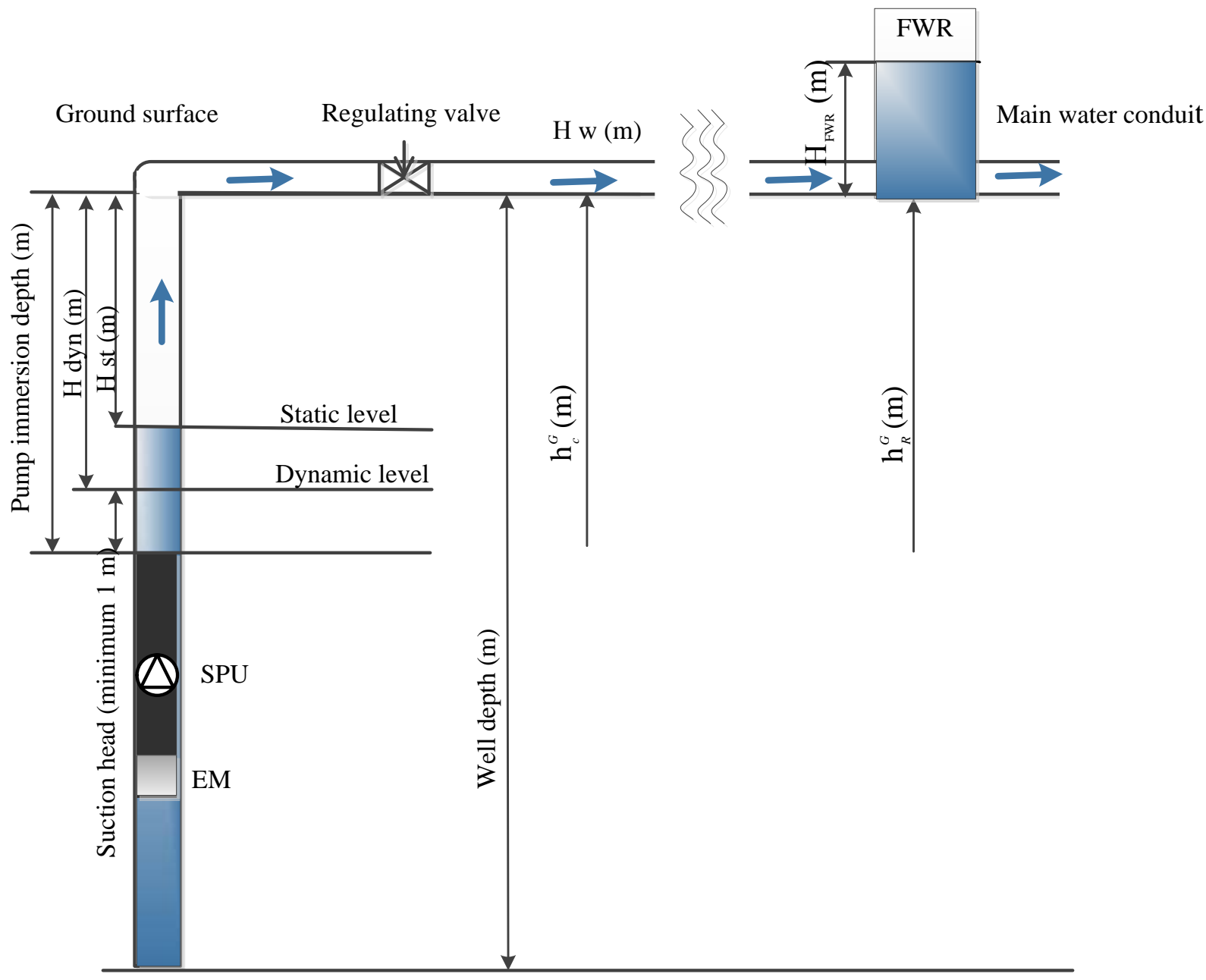

Fig. 1. The diagram of a pumping unit installation in the water-intake well

The Fig. 1 has the following designations: FWR - filtered-water reservoir, SPU - submersible pumping unit, $\mathrm{CP}$ - centrifugal pump, SEM - submersible electrical motor; $l_{\mathrm{SPU}}-$ SPU length; RV - regulating valve; the geodetic marks, respectively, are the following: mouth (ground surfaces) of a water-intake well $-h_{c}^{G}, \mathrm{CP}-h_{C P}^{G} ; \mathrm{FWR}-h_{R}^{G}$, well depth $h_{w}$, SPU immersion (installation) depth $h_{S P U}$; pressure: at the outlet (mouth) of the water intake well $-H_{w}$; pressure developed by a $\mathrm{CP}-H_{C P}$; water levels: in a FWR $H_{F W R}$; static level in the well (with zero water withdrawal) $-H_{s t}$; dynamic level in the well (at nominal water withdrawal) $-H_{d y n} ; \mathrm{CP}$ suction head level $-H_{C P}^{h}$.
When constructing a deterministic mathematical model of a water-intake well, it is assumed that all parameters of a water-intake well are known a priori. This allows you to determine the model of the water-intake well operation in the form of an interconnected system of algebraic equations of the following type:

$\mathrm{CP}$ geodesic mark:

$$
h_{C P}^{G}=h_{c}^{G}-h_{S P U}^{G}-0,5 l_{S P U} .
$$

CP suction head level:

$$
H_{C P}^{h}=h_{C P}^{G}-H_{d y n} .
$$

Pressure developed by a CP: 


$$
H_{\mathrm{CP}}(Q)=a_{0}+a_{1} \cdot Q+a_{2} \cdot Q^{2} .
$$

$\mathrm{CP}$ power expenditure:

$$
N_{\mathrm{CP}}(Q)=c_{0}+c_{1} \cdot Q+c_{2} \cdot Q^{2}
$$

CP efficiency coefficient:

$$
\eta(Q)=d+d \cdot Q+d \cdot Q
$$

where $Q$ - water consumed through a $\mathrm{CP}$, $a_{0}, a_{1}, a_{2}, c_{0}, c_{1}, c_{2}, d_{0}, d_{1}, d_{2}$ - numerical values of a $\mathrm{CP}$ parameters. The pressure loss $\mathrm{H}$ in the pipeline section $H=H(Q)$ is determined by the following expression

$$
H(Q)=\operatorname{sgn}(Q) \cdot \varphi \cdot|Q|^{\chi}
$$

where $Q$ - water flow through the pipeline section $\left[\mathrm{m}^{3} / \mathrm{sec}\right]$;

$\operatorname{sgn}(Q)-Q$ sign $; \varphi>0-$ hydraulic resistance of a pipeline section;

$\chi>0-$ K-rating factor.

The RV pressure loss in the $\mathrm{H}$ pipeline section is the following

$$
H_{V}=\frac{C}{E_{V}^{2}} \operatorname{sgn}(Q) \cdot|Q|,
$$

where $C$ - equivalent hydraulic resistance of the P3 in the "open" position;

$E_{V} \in(0,1]-\mathrm{RV}$ opening level, where $E_{V}=1$ in the "open" position; $E_{V}=0$ in the "close" position.

If the value of the water flow rate through the CP $Q$ is known, then the pressure value at the outlet (mouth) of the well is determined by the following expression

$$
H_{w}=H_{C P}^{h}+H_{C P}-H-H_{V} .
$$

Also, there are following relations:

$$
\begin{gathered}
H_{C P}^{h} \geq 1 m, \\
H_{s t} \leq H_{d y n} \leq h_{S P U} .
\end{gathered}
$$

\section{Stochastic model of a water well}

Water consumption processes are random processes, as they depend on many unmanageable and uncontrollable factors. The parameters of the WIF technological equipment are also random values, since they are estimated from experimental data of finite length [6]. We introduce a number of designations in order to construct stochastic models of the WIF technological elements: let us take $(\Omega, B, P)-$ as Descartes's product probability space $\left(\Omega_{i}, B_{i}, P_{i}\right), \quad i=1,2, \ldots, n$,

$\Omega=\Omega_{1} \times \Omega_{2} \times \ldots \times \Omega_{n}, \quad B=B_{1} \times B_{2} \times \ldots \times B_{n}$, $P=P_{1} \times P_{2} \times \ldots \times P_{n}$, where $\Omega_{i}-$ sample space; $B_{i}-\sigma$ - algebra of events from $\Omega_{i} ; P_{i}-$ probability measure at $\left.B_{i}\right)[11-13]$. Then the stochastic model of the water-intake well has the following form:

$$
\begin{aligned}
& H_{w}(\omega)=H_{C P}^{h}(\omega)+H_{C P}(\omega)-H(\omega)- \\
& -H_{V}(\omega) . \\
& H_{C P}(Q(\omega))=a_{0}(\omega)+a_{1}(\omega) Q(\omega)+ \\
& +a_{2}(\omega) Q^{2}(\omega) . \\
& H(Q(\omega))=\operatorname{sgn}(Q) \cdot \phi(\omega) \cdot|Q(\omega)|^{\chi} \\
& H_{V}(\omega)=\frac{C(\omega)}{E_{V}^{2}} \operatorname{sgn}(Q) \cdot|Q(\omega)| \\
& H_{C P}^{h}(\omega)=h_{C P}^{h}(\omega)-H_{d y n}(\omega) .
\end{aligned}
$$

\section{Stochastic model of a WIF}

In mathematical modeling and optimization of the WIF operation modes, we will use a stochastic model of the quasi-stationary WIF operating modes [7-9].

We will represent the WIF structure in the form of the $G(V, E)$ digraph, where $V-$ is the set of vertices, $E-$ is the set of $\operatorname{arcs}(e=$ Card $(E), v=$ Card $(V)$, the real WIF is supplemented by a zero vertex and fictitious chords that connect vertex zero with all inputs (wells) and its output (FWR). 
Let us consider a WIF with several artesian wells (Fig.2).

The following WIF coding is done for the mathematical formulation of the problem: the graph tree is chosen so that the fictitious sections of the network become chords, while the real sections become partly chords and partly branches of the tree. The branches of a tree with a pump are assigned number 1 , other branches are assigned from 2 to $v-1$, the chords of real sections are assigned from $v$ to $v+\eta_{2}-1$, the chords of fictitious sections are assigned with given nodal flows from $v+\eta_{2}$ to $v+\eta_{2}+\xi_{1}-1$, the chords of fictitious sections are assigned with given pressure from $v+\eta_{2}+\xi_{1}$ to e, where $\eta_{2}-$ is the number of chords of real sections, $\xi_{1}-$ is the number outputs with given nodal flow rates.

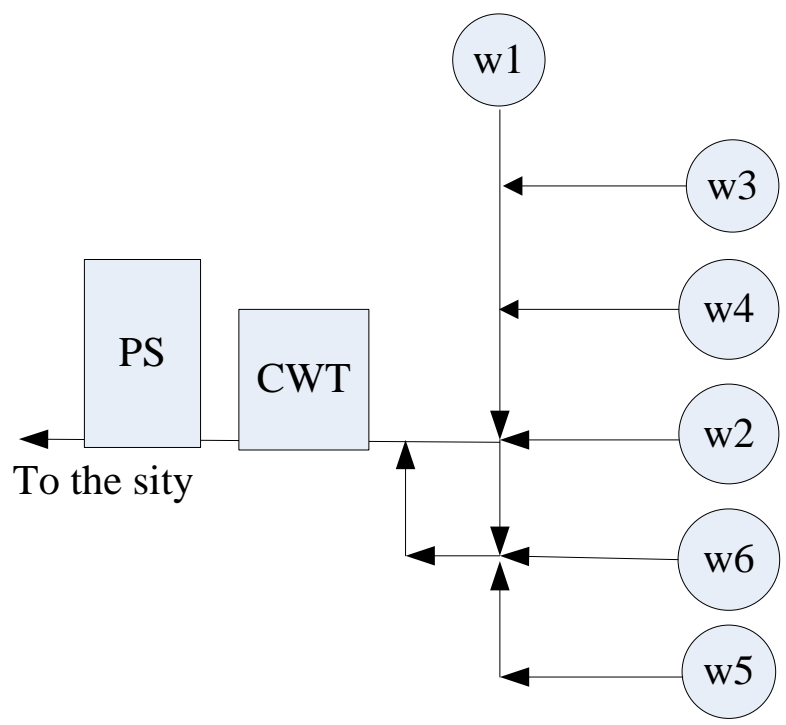

Fig. 2. WIF layout

In this case, the stochastic model of the quasi-stationary WIF operating modes will be of the following form[13]:

$$
\begin{gathered}
\Omega: \underset{\omega}{M}\left(H_{r}(Q(\omega))+\sum_{i=1}^{v-1} b_{1 r i} H_{i}(Q(\omega))\right)=0 \\
\left(r=v, \ldots, v+\eta_{2}-1\right)
\end{gathered}
$$

$$
\begin{aligned}
& \underset{\omega}{M}\left(h_{r}^{c}(\omega)-H_{c 1}(\omega)+\right. \\
& \left.\left.+\sum_{i=1}^{v-1} b_{1 r i} H_{r}(Q(\omega))+h_{i}^{g}\right)\right)=0, \\
& \left(r=v+\eta_{2}, \ldots, v+\eta_{2}+\xi_{1}-1\right), \\
& \underset{\omega}{M}\left(H_{r}(Q(\omega))+h_{r}^{g}-H_{c j}(\omega)+\right. \\
& \left.+H_{c 1}(\omega)+\sum_{i=1}^{v} b_{1 r i}\left(H_{i}(Q(\omega))+h_{i}^{g}\right)\right)=0, \\
& \left(r=v+\eta_{2}+\xi_{1}, \ldots, e ; j=1, \ldots, n\right), \\
& \underset{\omega}{M}\left(q_{i}(\omega)\right)=\underset{\omega}{M}\left(\sum_{r=v}^{v+\eta_{2}-1} b_{1 r i} Q_{r}(\omega)+\right. \\
& \left.+\sum_{r=v+\eta_{2}}^{e} b_{1 r i} Q_{r}(\omega)\right), \quad(i=1, \ldots, v-1) \text {. } \\
& P\left(h_{i}^{c}(\omega) \geq h_{i}^{+}\right) \geq \alpha, \quad(\alpha \cong 1), \\
& i=\left(v+\eta_{2}, \ldots, v+\eta_{2}+\xi_{1}-1\right), \\
& P\left(Q_{i}(\omega)>0\right) \cong \beta,(\beta \cong 1), i \in N, \\
& H_{w j}(\omega)=H_{C P j}^{h}(\omega)+H_{C P j}(\omega)- \\
& -H_{j}(\omega)-H_{V j}(\omega), \quad(j=1, \ldots, n) . \\
& H_{C P j}\left(Q_{j}(\omega)\right)=a_{0 j}(\omega)+a_{1 j}(\omega) Q_{j}(\omega)+ \\
& +a_{2 j}(\omega) Q_{j}^{2}(\omega), \quad(j=1, \ldots, n) . \\
& H_{k}\left(Q_{k}(\omega)\right)=\operatorname{sgn}\left(Q_{k}\right) \cdot \phi_{k}(\omega) \cdot\left|Q_{k}(\omega)\right|^{\chi} . \\
& k=\left(1, \ldots, v+\eta_{2}-1\right) \cup\left(v+\eta_{2}+\xi_{1}, \ldots, e\right) \\
& H_{V j}(\omega)=\frac{C_{j}(\omega)}{E_{V j}^{2}} \operatorname{sgn}\left(Q_{j}\right) \cdot\left|Q_{j}(\omega)\right| \text {. } \\
& (j=1, \ldots, n) \text {. } \\
& H_{C P j}^{h}(\omega)=h_{C P j}^{G}(\omega)-H_{d y n j}(\omega) \text {. } \\
& (j=1, \ldots, n),
\end{aligned}
$$

where random variables characterize the following: $Q_{j}(\omega)$ - water consumption at the $j$ section of the pipeline; $h_{r}^{c}(\omega)$ - free pressure 
in the WIF $r$-node $\left(r=v+\eta_{2}, \ldots, v+\eta_{2}+\xi_{1}-1\right) ; h_{r}^{+}-$the minimum admissible pressure in the WIF $r$-node; $h_{i}^{g}$-geodetic mark of the $i$-section of the pipeline $(i \in M) ; b_{1 r i}$-element of the cyclomatic matrix; $H_{w 1}(\omega)$-pressure at the output of the 1st source; $H_{w j}(\omega)$ - pressure at the output of the $j$-source $(j=2, \ldots, n) \in ; n$-is the number of wells.

We will use this WIF mathematical model to simulate and optimize the WIF operating modes.

\section{Stochastic model of the task on optimizing the WIF operating modes}

When a group of wells is operating on a common reservoir, a specific problem arises: pumping units on wells can operate in such a way that one pump is "squeezed" by another, which reduces the productivity of the entire WIF. To solve this problem, it is necessary to optimize the WIF operation.

We take the total water supply by all the WIF wells as a criterion by which we will optimize the WIF operation.

In words, the problem of optimizing the WIF operating modes can be formulated as follows: it is necessary to determine the parameters of the WIF processing equipment, at which the total water supply by all the WIF wells at a given control interval $[0, \mathrm{~T}]$ will be maximum. The parameters of the technological equipment that we will take into account are as follows: the operating points of the pumping units (flow and head), the immersion depth of the pumping units, and whether the pumping unit is turned on or off for a certain period of time[15 - 18].

The initial data for the task of optimizing the WIF operating modes are as follows: the control interval $[0, \mathrm{~T}]$ (one day), which is divided into 24 subintervals corresponding to each hour of the control period $\mathrm{k}=0, \ldots, 23$. At each k-subinterval of time, the measured values of the water levels in the FWR are known; the actual number of pumping units (PU) switched on, and static data: the WIF structure lengths, diameters, geodetic marks of the pipeline sections, estimates of the parameters of the PU models at each well, the FWR

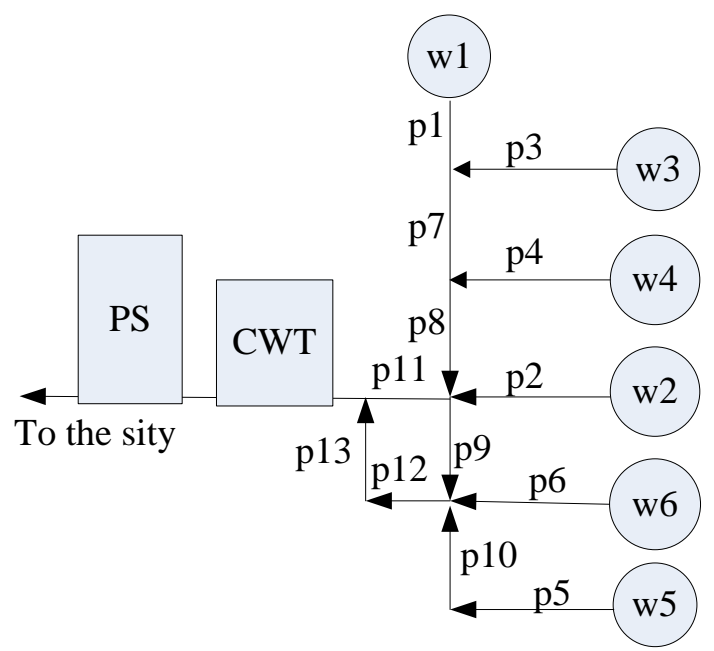

Fig. 3. WIF design diagram (p 1-13 mean a pipeline section, w1-6 mean wells)

physical dimensions [19-20].

The objective function of the problem on optimizing the WIF operating modes per day can be represented in the form of the mathematical expectation of the total water supply by all the WIF wells on the control interval $[0, \mathrm{~T}]$ :

$$
\underset{\omega}{M} \sum_{k=0}^{23} \sum_{i=1}^{n} Q_{w i k}(\omega) \rightarrow \max _{u(k) \in \Omega}
$$

where $n$ - number of wells, $u(k)$ - control vector. The $\Omega$ area of restrictions is determined by a stochastic model of quasistationary WIF operating modes (16) - (26).

\section{An example of a WIF operation simula- tor investigation}

As an example, consider a WIF consisting of six artesian wells, a reservoir of clean water, a second stage pumping station and pipeline sections, the design diagram of which is shown in Fig. 3.

Table $1-3$ shows a specification the artesian wells. 
Table 1. Specification of the artesian wells

\begin{tabular}{|c|c|c|c|c|c|c|}
\hline \multirow{2}{*}{ Parameters } & \multicolumn{6}{|c|}{ Well No } \\
\hline & 1 & 2 & 3 & 4 & 5 & 6 \\
\hline Diameter, $\mathrm{mm}$ & 200 & 200 & 200 & 200 & 200 & 200 \\
\hline Depth, m & 26 & 26 & 26 & 21,5 & 21,5 & 20 \\
\hline Static level depth, m & 3 & 2 & 3 & 4 & 4 & 4,5 \\
\hline Depth of the pump immersion, $\mathrm{m}$ & 17 & 15 & 20 & 18 & 18 & 18 \\
\hline Potential flow, $\mathrm{m}^{3} / \mathrm{h}$ & 30 & 35 & 20 & 25 & 25 & 25 \\
\hline Pump type & $\begin{array}{l}\text { ECWP } \\
\text { unit } 8- \\
40-90\end{array}$ & $\begin{array}{l}\text { ECWP } \\
\text { unit 8- } \\
25-100\end{array}$ & $\begin{array}{l}\text { ECWP } \\
\text { unit } 8- \\
40-90\end{array}$ & $\begin{array}{l}\text { ECWP } \\
\text { unit 8- } \\
40-90\end{array}$ & $\begin{array}{l}\text { ECWP } \\
\text { unit 8- } \\
40-90\end{array}$ & $\begin{array}{c}\text { ECWP } \\
\text { unit } 8-40- \\
90\end{array}$ \\
\hline Electric motor type & $\begin{array}{c}\text { SEM 8- } \\
17\end{array}$ & $\begin{array}{c}\text { SEM 6- } \\
11\end{array}$ & $\begin{array}{c}\text { SEM 8- } \\
17\end{array}$ & $\begin{array}{c}\text { SEM 8- } \\
17\end{array}$ & $\begin{array}{c}\text { SEM 8- } \\
17\end{array}$ & $\begin{array}{c}\text { SEM 8- } \\
17\end{array}$ \\
\hline Unit efficiency,\% & 82 & 82 & 82 & 82 & 82 & 82 \\
\hline Geodetic mark of the well mouth, $\mathrm{m}$ & 117,22 & 119 & 117,25 & 117,7 & 118 & 118,2 \\
\hline Geodetic mark of the pumping unit, $m$ & 97 & 104 & 97 & 100 & 100 & 100 \\
\hline $\mathrm{H}$ inlet, $\mathrm{m}$ ("level in the tank") & 14 & 14 & 17 & 13 & 14 & 13,5 \\
\hline
\end{tabular}

Table 2. Specification of the pipeline sections

\begin{tabular}{|c|c|c|c|c|}
\hline Pipeline section & Diameter, $\mathrm{mm}$ & Length, $\mathrm{m}$ & $\begin{array}{c}\text { Geodetic mark of the } \\
\text { beginning of the section, } \\
\mathrm{m}\end{array}$ & $\begin{array}{c}\text { Geodetic mark of the } \\
\text { finish of the section, } \\
\mathrm{m}\end{array}$ \\
\hline $\mathrm{p} 1$ & 100 & 76,73 & 117,22 & 117,3 \\
\hline $\mathrm{p} 2$ & 100 & 36,92 & 119 & 118,5 \\
\hline $\mathrm{p} 3$ & 100 & 27,24 & 117,25 & 117,3 \\
\hline $\mathrm{p} 4$ & 100 & 16,63 & 117,7 & 118,35 \\
\hline $\mathrm{p} 5$ & 100 & 49,33 & 118 & 118,5 \\
\hline $\mathrm{p} 6$ & 100 & 74,3 & 118,2 & 118,5 \\
\hline $\mathrm{p} 7$ & 200 & 44,31 & 118,35 & 118,5 \\
\hline $\mathrm{p} 8$ & 300 & 194,88 & 118,5 & 118,5 \\
\hline $\mathrm{p} 9$ & 500 & 77,25 & 118,5 & 118,5 \\
\hline $\mathrm{p} 10$ & 500 & 10 & 118,5 & 105 \\
\hline $\mathrm{p} 11$ & 300 & 13800,71 & 118,5 & 105 \\
\hline $\mathrm{p} 12$ & 300 & 13311,59 & 118,5 & 105 \\
\hline $\mathrm{p} 13$ & 300 & 15 & 105 & \\
\hline
\end{tabular}

Table 3. Specification of the FWR

\begin{tabular}{|l|c|}
\hline FWR volume, $\mathrm{m}^{3}$ & 1000 \\
\hline Geodetic mark of the bottom, $\mathrm{m}$ & 106 \\
\hline Maximum water level, $\mathrm{m}$ & 5 \\
\hline Minimum water level, $\mathrm{m}$ & 1 \\
\hline
\end{tabular}

\section{Calculation results}

Tables $4-6$ show the WIF parameters for various WIF operating modes. 
Table 4. WIF parameters for various operating modes

\begin{tabular}{|c|c|c|c|c|c|}
\hline \multicolumn{6}{|c|}{ FWR initial level of $1,5 \mathrm{~m}$} \\
\hline $\begin{array}{c}\text { All the wells } \\
\text { operate }\end{array}$ & $\begin{array}{c}\text { Pressure after } \\
\text { the PU, m }\end{array}$ & $\begin{array}{l}\text { Consumption in wells, } \\
\mathrm{m}^{3} / \mathrm{h}\end{array}$ & $\begin{array}{l}\text { Consump- } \\
\text { tion in water } \\
\text { pipeline } 1 \\
\text { before the } \\
\text { FWR, } \mathrm{m}^{3} / \mathrm{h}\end{array}$ & $\begin{array}{l}\text { Consump- } \\
\text { tion in water } \\
\text { pipeline } 2 \\
\text { before the } \\
\text { FWR, } \mathrm{m}^{3} / \mathrm{h}\end{array}$ & $\begin{array}{c}\text { FWR } \\
\text { inflow, } \\
\mathrm{m}^{3} / \mathrm{h}\end{array}$ \\
\hline Well 1 & 75,59 & 46,52 & \multirow{6}{*}{134,51} & \multirow{6}{*}{132,16} & \multirow{6}{*}{266,67} \\
\hline Well 3 & 74,00 & 47,32 & & & \\
\hline Well 4 & 73,04 & 47,35 & & & \\
\hline Well 2 & 71,61 & 33,35 & & & \\
\hline Well 6 & 75,59 & 45,64 & & & \\
\hline Well 5 & 74,60 & 46,48 & & & \\
\hline
\end{tabular}

Table 5. WIF parameters for various operating modes

\begin{tabular}{|c|c|c|c|c|c|}
\hline & & FWR initial level of 3,7 & & & \\
\hline $\begin{array}{l}\text { All the wells } \\
\text { operate }\end{array}$ & $\begin{array}{l}\text { Pressure after } \\
\text { the PU, m }\end{array}$ & $\begin{array}{l}\text { Consumption in wells, } \\
\mathrm{m}^{3} / \mathrm{h}\end{array}$ & $\begin{array}{l}\text { Consump- } \\
\text { tion in water } \\
\text { pipeline } 1 \\
\text { before the } \\
\text { FWR, } \mathrm{m}^{3} / \mathrm{h}\end{array}$ & $\begin{array}{l}\text { Consump- } \\
\text { tion in water } \\
\text { pipeline } 2 \\
\text { before the } \\
\mathrm{FWR}, \mathrm{m}^{3} / \mathrm{h}\end{array}$ & $\begin{array}{c}\text { FWR } \\
\text { inflow, } \\
\mathrm{m}^{3} / \mathrm{h}\end{array}$ \\
\hline Well 1 & 79,70 & 44,15 & \multirow{6}{*}{125,62} & \multirow{6}{*}{127,86} & \multirow{6}{*}{253,48} \\
\hline Well 3 & 78,27 & 44,91 & & & \\
\hline Well 4 & 77,35 & 44,91 & & & \\
\hline Well 2 & 75,96 & 32,12 & & & \\
\hline Well 6 & 79,59 & 43,29 & & & \\
\hline Well 5 & 78,73 & 44,10 & & & \\
\hline
\end{tabular}

Table 6. WIF parameters for various operating modes

\begin{tabular}{|c|c|c|c|c|c|}
\hline & & FWR initial level of 4,8 & & & \\
\hline $\begin{array}{c}\text { All the wells } \\
\text { operate }\end{array}$ & $\begin{array}{l}\text { Pressure after } \\
\text { the PU, m }\end{array}$ & $\begin{array}{l}\text { Consumption in wells, } \\
\mathrm{m}^{3} / \mathrm{h}\end{array}$ & $\begin{array}{l}\text { Consump- } \\
\text { tion in water } \\
\text { pipeline } 1 \\
\text { before the } \\
\text { FWR, } \mathrm{m}^{3} / \mathrm{h}\end{array}$ & $\begin{array}{l}\text { Consump- } \\
\text { tion in water } \\
\text { pipeline } 2 \\
\text { before the } \\
\text { FWR, } \mathrm{m}^{3} / \mathrm{h}\end{array}$ & $\begin{array}{c}\text { FWR } \\
\text { inflow, } \\
\mathrm{m}^{3} / \mathrm{h}\end{array}$ \\
\hline Well 1 & 80,05 & 43,94 & \multirow{6}{*}{127,29} & \multirow{6}{*}{125,06} & \multirow{6}{*}{252,34} \\
\hline Well 3 & 78,62 & 44,70 & & & \\
\hline Well 4 & 77,71 & 44,70 & & & \\
\hline Well 2 & 76,32 & 32,01 & & & \\
\hline Well 6 & 79,93 & 43,09 & & & \\
\hline Well 5 & 79,08 & 43,90 & & & \\
\hline
\end{tabular}


The Tables 4 - 6 show how the WIF parameters change for different initial water levels of the FWR. The lower the initial water level of the FWR, the greater the water supply by the wells (water inflow into the FWR) and the lower the pressure at the PU outlets. One of the ways to further optimize the WIF operation could be the use of a three-zone tariff for electricity and the use of the FWR capacity in a wider range [8]; however, the results obtained cast doubt on the feasibility of such an approach. This will be the focus of further research.

\section{DISCUSSION OF THE RESULTS OF THE STUDY}

As a result of handling the challenge of optimizing the WIF operating modes, such a mode of the WIF operation and such parameters of the technological equipment were found, in which the pumping units in the wells do not "strangle" each other, but coherently operate, while the water supply to the WIF is maximum. The calculation results given in Tab. $4-6$, show the WIF optimal operating mode, i.e. operating points of pumping units on wells (columns 2,3) and the maximum water supply to the WIF (column 6) at different water levels in the FWR.

\section{CONCLUSIONS}

A stochastic model of the WIF operation modes is developed in this scientific paper. The problem of optimizing a WIF operation modes, which consists in the fact that it is necessary to find such a WIF operation mode and such parameters of the technological equipment so that the water supply to the WIF is maximum, was formulated and solved based on this stochastic model. The calculation example shows all the initial data for the problem and the results of calculations.

\section{REFERENCES}

1. Zamyatin N.V., Ivanov E.O., 2011. Automation of calculating the productivity of pressure head artesian wells in the Simulink environment. Management, computer technology and informatics. TUSUR reports, No.2 (24), Part 3, 154-158 (Russian).

2. Zamyatin N.V., Ivanov E.O., 2015. Fuzzy advising control system for artesian wells. Management, computer technology and informatics. TUSUR reports, No.4 (38), 178-181 (Russian).

3. Marugin A.P., Sadovnikov M.E., 2001. System of dispatching control and control of pumps of artesian wells. Bulletin of the Ural State Mining University, No.12, 101-104 (Russian).

4. Polishchuk C. I., Kutran I. S., 2011. Saving electricity in artesian water supply systems. Energy Saving Technologies. Energy saving. Energy. Energy audit, No.5 (87), 79-82 (Russian).

5. Jinlon Wang, Zolotukhin A.B., Zhou Qiaofeng, Ibragimov Zh.Zh., Zhang Ningsheng, 2018. Optimization of high-tech wells. Neftegaz.RU, No.6, 39-45 (Russian).

6. Grava A., Rotiroti M., Fumagalli L., Bonomi N., 2016. Optimization of Well System Using the Ground Water Management Package of MODFLOW-2000. Department of Earth and Environmental Sciences, University of MilanoBicocca, Piazza della Scienza, No.39, 101-104.

7. Teviashev A. D., Matvienko O. I., 2014. About one Approach to Solve the Problem of Management of the Development and Operation of Centralized Water-Supply Systems. Econtechmod. An International Quarterly Journal, Vol.3 (3), 61-76. DOI: 10.15587/17294061.2015.55469.

8. Teviashev A.D., Matvienko O. I., 2015. Mathematical Model and Method of Optimal Stochastic Control of the Modes of Operation of the Water Main. East-European Journal of Enterprise Technologies, Vol.6/4(78), 45-53.

9. Tevyashev A., Matviyenko O., Nikitenko G., 2019. Construction of a Stochastic Model for a Water Supply Network with Hidden Leaks and a Method for Detecting and Calculating the Leaks. Eastern-European Journal of Enterprise Technologies, Vol.6/4 (102), 29-38.

10. Krishna Kayastha, 2015. Application of bell type water well with wide gravel filter. Underwater Technologies: Industrial and Civil Engineering, Vol.01, 65-76. 
11. Tevyashev A., Matvienko O., 2016. Estimation of the potential of resource and energy saving in the management of development and functioning of water main. Underwater Technologies, Vol.04, 26-37 (Russian).

12. Tevyashev A., 2018. Information and analytical technology for optimal management of sustainable development and functioning of water supply systems. Underwater Technologies, Vol.08, 47-49 (Russian).

13. Tevyashev A., Matvienko O., Nikitenko G., 2021. Stochastic model and optimization method for robotic groups of artesian deep holes in water supply systems. Transfer of Innovative Technologies, Vol.4, No.1, 108-110 (Ukrainian).

14. Leznov B.C. 2006. Energy saving and adjustable drive for pump and blower installations. Moscow. Energoatomizdat, 358 (Russian).

15. Novohatny B., Kostenko S. 2013. Reliability of water supply conduits. Motrol. Commission of Motorization and Energetics in Agriculture Polish Academy of Sciences University of Engineering and Economics in Rzeszow. LublinRzeszow. Vol.15, No.6, 101-109.

16. Pulido-Calvo I. Gutiérrez-Estrada J. C. 2011. Selection and Operation of Pumping Stations of Water Distribution Systems. Environmental Research Journal, Nova Science Publishers, 1-20.

17. Ruuskanen A. 2007. Optimization of Energy Consumption in Wastewater Pumping. Lappeenranta University of Technology Department of Energy- and Environmental Technology, 99.

18. Saliev E. 2013. Reliability of the Functioning of the Water Supply and Sewerage System. Motrol. Commission of Motorization and Energetics in Agriculture Polish Academy of Sciences University of Engineering and Economics in Rzeszow. Lublin-Rzeszow. Vol.15, No.5, 5361.

19. Steinbach M.C. 2001. General Information Constraints in Stochastic Programs. Berlin: ZIB, 5.

20. Steinbach M.C. 2001. Tree-Sparse Convex Programs. Konrad-Zuse-Zentrum fur Informationstechnik Berlin, ZIB-Report, 22.

\section{Стохастическая модель и метод оптимизации режимов работы группы артезианских скважин в системах водоснабжения}

\section{Андрей Тевямев, Ольга Матвиенко, Глеб Никитенко}

Аннотация. Для обеспечения питьевой водой населённых пунктов в системах водоснабжения используют группы пространственно распределённых скважин, объединённых между собой участками трубопроводов (общим коллектором), подающим воду в резервуар чистой воды. Группа скважин совместно с резервуаром чистой воды называется водозаборным узлом системы водоснабжения. Далее из резервуара чистой воды насосными станциями второго подъёма вода подаётся потребителям в населенные пункты. Режим работы погружного насосного агрегата, т.е. положение его рабочей точки в фиксированный момент времени, для каждой скважины зависит от фактических значений множества внутренних и внешних факторов: динамического уровня воды в скважине; фактических характеристик насосного агрегата; положения регулирующих органов (оборотов привода, степени открытия регулирующей задвижки); гидравлических сопротивлений участков трубопроводов водозаборного узла; уровня воды в резервуаре чистой воды; количества и режимов работы насосных агрегатов в других скважинах водозаборного узла.

В работе дана детерминированная модель водозаборной скважины. В то же время процессы водопотребления являются случайными процессами, поскольку зависят от многих неконтролируемых и неуправляемых факторов. Параметры технологического оборудования водозаборного узла также являются случайными величинами, так как оцениваются по экспериментальным данным конечной длины.

Поэтому предложена также стохастическая модель водозаборной скважины Рассмотрена модель квазистационарного режима работы водозаборного узла, которая используется для оптимизации работы группы артезианских скважин, работающих на общий коллектор.

Ключевые слова: артезианская скважина; система водоснабжения; оптимизация; стохастическая модель, насосный агрегат, водозаборный узел. 